\section{Elevated Levels of Potassium in Greenhouse-grown Red Romaine Lettuce Impacts Mineral Nutrient and Soluble Sugar Concentrations}

\author{
T. Casey Barickman² and Thomas E. Horgan ${ }^{1}$ \\ North Mississippi Research and Extension Center, Mississippi State \\ University, Verona, MS 38879
}

\section{Jennifer R. Wheeler ${ }^{1}$ and Carl E. Sams \\ Department of Plant Sciences, The University of Tennessee, Knoxville, TN 37996}

Additional index words. Lactuca sativa, fertilizer management, fructose, glucose, sucrose

\begin{abstract}
Lettuce is one of the major crops of the United States and can provide a large portion of income for small to medium size growers. Growing lettuce in adverse environmental conditions can have negative effects on quality. Elevated levels of potassium (K) have been shown to positively influence quality in various fruits and vegetables, such as tomato, pepper, and strawberry. However, research is lacking on the effects of elevated levels of $K$ on leafy vegetables such as lettuce. Therefore, seeds of 'Cimmaron' lettuce were sown into a soilless medium and grown in greenhouse conditions at $25 / 20^{\circ} \mathrm{C}$ (day/night). At 27 days after seeding, the plantlets were transferred to 3.8-L plastic nursery pots. Plants were grown under increasing $K$ treatments of 98 (control), $185(2 \times), 370(3 \times)$, and $740(8 \times) \mathrm{kg} \mathrm{ha}^{-1}$. Plants were harvested 56 days after seeding. Application of elevated levels of $\mathrm{K}$ fertilizer treatments in red romaine lettuce had a positive quadratic effect on plant height increasing $7.0 \%$ from the control. Fresh weight (FW) increased $13.0 \%$ from the control and dry weight (DW) increased $15.5 \%$. There was linear increase of $30.0 \%$ in sucrose concentrations in lettuce leaf tissue. In addition, the increase in $K$ treatments caused an increase of $43.3 \%$ in $K$ concentrations in the leaf tissue. In other nutrients, such as Calcium (Ca), Magnesium (Mg), and Sulfur (S), there was a decrease in the leaf tissue of $61 \%, 52 \%$, and $46 \%$ when compared with the control treatment, respectively. The results of the current study suggest that increasing $\mathrm{K}$ fertilizer to $185 \mathrm{~kg} \cdot \mathrm{ha}^{-1}$ has the best results for plant height, FW and DW, and mineral nutrient concentrations. This study may initiate research that could examine the effects of increasing $\mathrm{K}$ fertilizer levels in lettuce or other leafy green vegetables on antioxidant levels and postharvest storability.
\end{abstract}

Open field and greenhouse production of lettuce (Lactuca sativa) in southern United States occurs predominately in the fall and winter seasons due to lower temperatures and shorter days. In most southern states, lettuce provides a large amount of income. Romaine type lettuce is the main lettuce grown by small to medium producers. Depending on plant spacing, the average yields of romaine lettuce can be around 30,000 kg.ha ${ }^{-1}$ (Mossler and Dunn, 2005). Romaine type lettuce is a preferred leafy green grown in these operations because of consumer preferences due to its higher nutritional value compared with head type lettuce. In adverse environmental

\footnotetext{
Received for publication 19 Nov. 2015. Accepted for publication 29 Feb. 2016.

This research was made possible through support from USDA NIFA Hatch S-294 project MIS 149160 and Mississippi State University, Mississippi Agriculture and Forestry Experiment Station.

${ }^{1}$ Research Associate.

${ }^{2}$ Corresponding author. E-mail: t.c.barickman@ msstate.edu.
}

conditions, such as high temperatures and inadequate fertilization, lettuce can decrease in quality by having long internodes, becoming bitter in taste, and having increased incidences of tipburn (Bres and Weston, 1992; Eskins et al., 1995). For example, lettuce grown under limited $\mathrm{Ca}$ had a chlorotic appearance and reduced growth. Lack of boron (B) also caused lettuce to have wrinkled leaf tissue, lose apical dominance, and exhibit limited plant growth (Petrazzini et al., 2014). In addition, Luo et al. (2012) found that increasing $\mathrm{K}$ in lettuce plants elevated soluble sugar, starch, and leaf $\mathrm{K}$ concentrations when grown under different root-zone temperatures. On the other hand, effects of different temperature regimes resulted in differences in chlorophyll and anthocyanin content in greenhouse-grown red leaf lettuce (Kleinhenz et al., 2003). Thus, growing lettuce under adverse environmental conditions can have an unfavorable effect on growth, yield, and quality.

Potassium is vital to plant growth, yield, and quality even though it is not a constituent of any functional molecules or plant structures (Marschner, 2012). In addition, it helps to regulate stomatal conductance and photosynthesis. Potassium is also involved in photophosphorylation, transport of photoassimilates from source to sink tissues via the phloem, enzyme activation, turgor maintenance, and stress tolerance (Marschner, 2012). However, K may be best known to positively influence many qualities of fruits and vegetables. Previous research has demonstrated that $\mathrm{K}$ fertilizer applied to the soil enhanced color, increased fruit tissue firmness, and elevated soluble sugar concentrations in apple (Malus $\times$ domestica) fruit tissue (Nava et al., 2008). However, contrasting results have been indicated in previous research. For instance, Fallovo et al. (2009a) examined how different nutrition solution concentrations affected lettuce yield and quality. The results indicated that the effect of the growing season on yield and quality was more prominent than that of the nutrient solution composition. Thus, results from $\mathrm{K}$ research studies are variable in different plant species for growth, yield, and quality.

Research has indicated that supplemental $\mathrm{K}$ nutrition has been associated with increased fruit size and higher soluble solid and ascorbic acid concentrations (Lester et al., 2005). Studies have shown that supplemental $\mathrm{K}$ increases yield and carotenoids in vegetables such as tomato (Solanum lycopersicum) (Fanasca et al., 2006; Taber et al., 2008) and pepper (Capsicum annuum) (Anathi et al., 2004), and size, color, firmness, and sugar content in tree fruits, such as apple (Wojcik, 2005) and citrus (Dutta et al., 2003; Srivastava et al., 2001). Some of the most successful supplemental K research has been conducted on muskmelon (Cucumis melo). For example, Lester et al. $(2005,2006)$ found that supplemental applications of $\mathrm{K}$ increased fruit firmness, vitamins, sugars, and yield. In addition, Jifon and Lester (2009) examined different forms of $\mathrm{K}$ fertilization to improve quality of fieldgrown muskmelons. They found that late season foliar $\mathrm{K}$ applications increased tissue $\mathrm{K}$ concentration, fruit sugars, and bioactive compounds such as ascorbic acid and $\beta$-carotene.

Research associated with adequate and elevated levels of $\mathrm{K}$ on lettuce yield and quality is limited and inconclusive. Some studies found that $\mathrm{K}$ in nutrient solution did not affect lettuce yield and quality. For example, Fallovo et al. (2009b) investigated the effects of macro-anion and cation ratios in hydroponic lettuce in two different seasons. The results indicated that the change in season from spring to summer and increasing the fertilizer concentrations increase plant growth and yield. Soundy et al. (2001) demonstrated that increasing levels of $\mathrm{K}$ in the nutrient solution from 15 to $60 \mathrm{mg} \cdot \mathrm{L}^{-1}$ increased fresh and dry root weight at $28 \mathrm{~d}$ after transplant. Other studies found inconclusive results on the effects of $\mathrm{K}$ applications. Bres and Weston (1992) demonstrated that increasing $\mathrm{pH}$ levels at two different $\mathrm{K}$ concentrations did not affect tipburn 
incidence in hydroponically grown lettuce. In addition, Hoque et al. (2010) applied different combinations of nitrogen $(\mathrm{N})$, phosphorus (P), and $\mathrm{K}$ but concluded that $\mathrm{K}$ did not affect quality compared with $\mathrm{N}$ and $\mathrm{P}$. The limited research for $\mathrm{K}$ treatment effects on lettuce yield and quality demonstrate some positive results; however, more research is needed to explain variable results. The purpose of this study was to determine the effect of adequate and elevated levels of $\mathrm{K}$ on greenhousegrown lettuce plant height, biomass accumulation, mineral nutrient uptake, and soluble sugar concentrations.

\section{Materials and Methods}

Plant material, growing conditions, and treatments. Seeds of 'Cimmaron' lettuce (Harris Seeds, Rochester, NY) were sown into Pro-Mix BX soilless medium (Premier Tech Horticulture, Québec, Canada) and germinated in greenhouse conditions at 25/ $20{ }^{\circ} \mathrm{C}$ (day/night). At $27 \mathrm{~d}$ after seeding, the plantlets were transferred to $3.8-\mathrm{L}$ plastic nursery pots filled with Pro-Mix BX soilless medium. Plants were fertilized with $28 \mathrm{~g}$ (Osmocote; Scotts Miracle-Gro, Marysville, $\mathrm{OH})$ of $15 \mathrm{~N}-3.9 \mathrm{P}-9.9 \mathrm{~K}$. The $\mathrm{N}, \mathrm{P}$, and $\mathrm{K}$ were then calculated on a $\mathrm{kg} \cdot \mathrm{ha}^{-1}$ basis. Elemental concentrations of nutrients applied to the plants were $\left(\mathrm{kg} \cdot \mathrm{ha}^{-1}\right)$ : nitrogen $(\mathrm{N} ; 139)$ and phosphorus $(\mathrm{P} ; 36)$. Plants were grown under increasing $\mathrm{K}$ treatments of 98 (control), $185(2 \times), 370(3 \times)$, and $740(8 \times)$ $\mathrm{kg} \cdot \mathrm{ha}^{-1}$. Elevated K treatments were applied as potash $(0 \mathrm{~N}-0 \mathrm{P}-49.8 \mathrm{~K})$. The experiment was carried out on 16 Sept. 2014 and on 2 Mar. 2015. Natural photoperiod and intensity of sunlight averaged $350 \mu \mathrm{mol} \cdot \mathrm{m}^{-2} \cdot \mathrm{s}^{-1}$ over the entire photoperiod. Light intensity readings were taken at $1.22 \mathrm{~m}$ off the ground. Experimental design was a randomized complete block with four $\mathrm{K}$ treatments, four replications, and five individual pots representing an experimental unit with one lettuce plant per pot. Treatments of elevated $\mathrm{K}$ were sidedressed at three different times during the experiment at $1 / 3$ the amount of the full treatment total. Plants were harvested at $54 \mathrm{~d}$ after seeding. Subsequently, lettuce plants from each treatment were separated by replication and weighed for biomass. At least three leaves from each experimental unit were subsampled, frozen, and prepared for elemental nutrient and soluble sugars. Samples were stored at $-20{ }^{\circ} \mathrm{C}$ before analysis.

Mineral composition. Nutrient analysis was conducted according to Barickman et al. (2013) with slight modifications. In brief, leaves were collected and dried for $48 \mathrm{~h}$ in a forced air oven (model large; Fisher Scientific, Atlanta, GA) at $65{ }^{\circ} \mathrm{C}$. Dried samples were ground to homogeneity using liquid nitrogen, and 0.5 -g subsamples were combined with $10 \mathrm{~mL}$ of $70 \% \mathrm{HNO}_{3}$ and digested in a microwave digestion unit (Model: Ethos; Milestone Inc., Shelton, CT). Nutrient analysis was conducted using an inductively coupled plasma mass spectrometer (ICP-MS; Agilent
Technologies, Inc., Wilmington, DE). The ICP-MS system was equipped with an octapole collision/reaction cell, Agilent 7500 ICP-MS ChemStation software, a Micromist nebulizer, a water-cooled quartz spray chamber, and a CETAC (ASX-510, CETAC Inc., Omaha, NE) auto-sampler. The instrument was optimized daily in terms of sensitivity (lithium: Li, yttrium: Y, thallium: Tl), level of oxide, and doubly charged ion using tuning solution containing $10 \mu \mathrm{g} \cdot \mathrm{L}^{-1}$ of $\mathrm{Li}$, $\mathrm{Y}, \mathrm{Tl}$, cerium $(\mathrm{Ce})$, and cobalt $(\mathrm{Co})$ in a $2 \%$ $\mathrm{HNO}_{3} / 0.5 \% \mathrm{HCl}(\mathrm{v} / \mathrm{v})$ matrix. Tissue nutrient concentrations are expressed on a DW basis.

Soluble sugar analysis. Soluble sugar analysis was conducted according to Barickman et al. (In press). In brief, lettuce leaf samples were ground in a bullet grinder for homogenous subsamples. A 2.0-g subsample was extracted in a $15-\mathrm{mL}$ test tube by adding $2 \mathrm{~mL}$ of reverse osmosis (RO) water, vortexing, and shaking for $15 \mathrm{~min}$ at $200 \mathrm{rpm}$. Samples were then centrifuged at $4000 \mathrm{rpm}$ for $10 \mathrm{~min}$, and $1.0 \mathrm{~mL}$ of the supernatant was transferred into a new $15-\mathrm{mL}$ test tube. After the transfer, $1.4 \mathrm{~mL}$ of acetonitrile was added, and tubes were mixed by inversion and kept at room temperature for $30 \mathrm{~min}$. Samples were then centrifuged at $4000 \mathrm{rpm}$ for $10 \mathrm{~min}$, and $1.0 \mathrm{~mL}$ of the supernatant was transferred into a new $15-\mathrm{mL}$ tube and placed into a dry bath until complete evaporation. Once dried, samples were dissolved in $0.5 \mathrm{~mL}$ of $75 \%$ acetonitrile and $25 \%$ RO water. Samples were then put through a $0.2-\mu \mathrm{m}$ syringe filter and collected in a $2 \mathrm{~mL}$-high performance liquid chromatography (HPLC) vial for analysis. Separation parameters and sugar quantification were carried out with authentic standards using an Agilent 1100 series HPLC with a refractive index detector (Agilent Technologies). Chromatographic separations were achieved using a $250 \times 4.6 \mathrm{~mm}$ i.d. $5 \mu \mathrm{m}$ analytical scale $\mathrm{NH}_{2}$ (amino) carbohydrate $\mathrm{C}_{18}$ reverse-phase column (Agilent Technologies), which allowed for effective separation of chemically similar sugar compounds. The column was equipped with a Zorbax $\mathrm{NH}_{2} 4.6 \times 12.5 \mathrm{~mm}$ i.d. guard cartridge and holder (Agilent Technologies), and was maintained at $30{ }^{\circ} \mathrm{C}$ using a thermostatted column compartment. All separations were achieved isocratically using a binary mobile phase of $75 \%$ acetonitrile and $25 \%$ RO water $(\mathrm{v} / \mathrm{v})$. The flow rate was $1.0 \mathrm{~mL} \cdot \mathrm{min}^{-1}$, with a run time of $15 \mathrm{~min}$, followed by a 2-min equilibration before the next injection. Eluted compounds from a $10-\mu \mathrm{L}$ injection loop were detected in positive detection mode, and data were collected, recorded, and integrated using ChemStation Software (Agilent Technologies). Peak assignment for individual sugars was performed by comparing retention times from the refractive index detector using external standards of fructose and glucose (Sigma-Aldrich, St. Louis, MO).

Statistical analysis. The experimental design was a randomized complete block with four $\mathrm{K}$ treatments and four replications. The two experiments were statistically similar. Therefore, data were pooled and analyzed together for treatment means. The fixed effect for the experiment consisted of the four $\mathrm{K}$ treatments, whereas replications were analyzed as random effects. The standard errors were based on the pooled error term from the analysis of variance table. Modelbased values were reported rather than unequal standard error from a databased calculation because pooled errors reflect the statistical testing being done. Orthogonal polynomials were used to study changes associated with $\mathrm{K}$ treatments by partitioning the sums of squares into components associated with linear and quadratic terms. Diagnostic tests were conducted to insure that treatment variances were statistically equal before pooling.

\section{Results}

$K$ influence on plant growth and biomass production of red romaine lettuce. Increasing $\mathrm{K}$ treatments significantly influenced lettuce biomass. Fresh weight had a positive quadratic response with increasing levels of $\mathrm{K}$ treatments (Fig. 1). Levels of FW were $526.4 \mathrm{~g}$ in the control treatment, increasing $11 \%$ in $2 \times \mathrm{K}$ treatments, and then decreasing $26 \%$ from the $2 \times$ to the $8 \times \mathrm{K}$ treatments. Correspondingly, DW had a positive quadratic response with increasing K treatment levels (Fig. 2). Levels of DW were $48.5 \mathrm{~g}$ in the control treatment, increasing $16 \%$ in $2 \times \mathrm{K}$ treatments, and then decreasing $35 \%$ from the $2 \times$ to the $8 \times \mathrm{K}$ treatments. Similarly, plant heights had a positive quadratic response with increasing $\mathrm{K}$ treatment levels (Fig. 3). Plant height was $32.4 \mathrm{~cm}$ in the control treatment, increasing $7 \%$ in $2 \times \mathrm{K}$ treatments, and then decreasing $5 \%$ in the $8 \times \mathrm{K}$ treatment.

Kinfluence on mineral nutrient concentration in leaf tissue. Increasing levels of $\mathrm{K}$ significantly increased $\mathrm{K}$ concentrations in the leaf tissue of red romaine lettuce. Levels of $\mathrm{K}$ increased linearly by $40 \%$ when comparing the control to the $8 \times$ treatment. In contrast, there was a decrease in the levels of $\mathrm{Na}, \mathrm{Mg}$, $\mathrm{S}, \mathrm{Ca}, \mathrm{B}$, and $\mathrm{Fe}$ in the leaf tissue of red romaine lettuce. With increased rates of $\mathrm{K}$ fertilizer treatments, $\mathrm{Na}$ decreased linearly by $40 \%$ from the control to the $8 \times \mathrm{K}$ treatment. Levels of $\mathrm{Mg}$ decreased $52 \%$, in the $8 \times \mathrm{K}$ treatment when compared with the control. Similarly, S decreased $46 \%$, Ca decreased $61 \%$, B decreased $33 \%$, and $\mathrm{Fe}$ decreased 42\% (Table 1). Furthermore, levels of $\mathrm{Mn}, \mathrm{Cu}$, and $\mathrm{Zn}$ had a positive quadratic response with increasing levels of $\mathrm{K}$ treatments. Levels of $\mathrm{Mn}$ increased $27 \%$ in the $2 \times \mathrm{K}$ treatments while decreasing $57 \%$ in the $8 \times \mathrm{K}$ treatments. Similarly, levels of $\mathrm{Cu}$ were $0.02 \mathrm{mg} \cdot \mathrm{g}^{-1} \mathrm{DW}$ in the control treatment, increasing $60 \%$ in $2 \times \mathrm{K}$ treatment while decreasing $60 \%$ in the $3 \times$ and $8 \times \mathrm{K}$ treatments. Levels of $\mathrm{Zn}$ were $0.07 \mathrm{mg} \cdot \mathrm{g}^{-1} \mathrm{DW}$ in the control treatment, increasing $22 \%$ in the $2 \times \mathrm{K}$ treatment while decreasing $11 \%$ in $3 \times \mathrm{K}$ treatment and $33 \%$ in $8 \times \mathrm{K}$ treatment (Table 1 ). There were no 


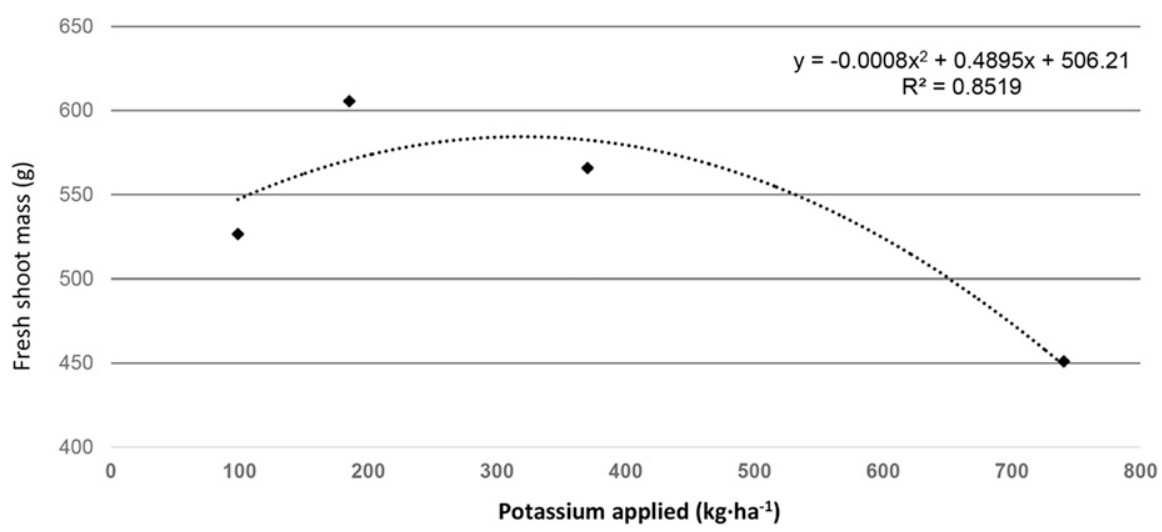

Fig. 1. The effect of adequate and elevated levels of potassium on fresh weight of greenhouse-grown red romaine lettuce plants harvested $56 \mathrm{~d}$ after seeding.

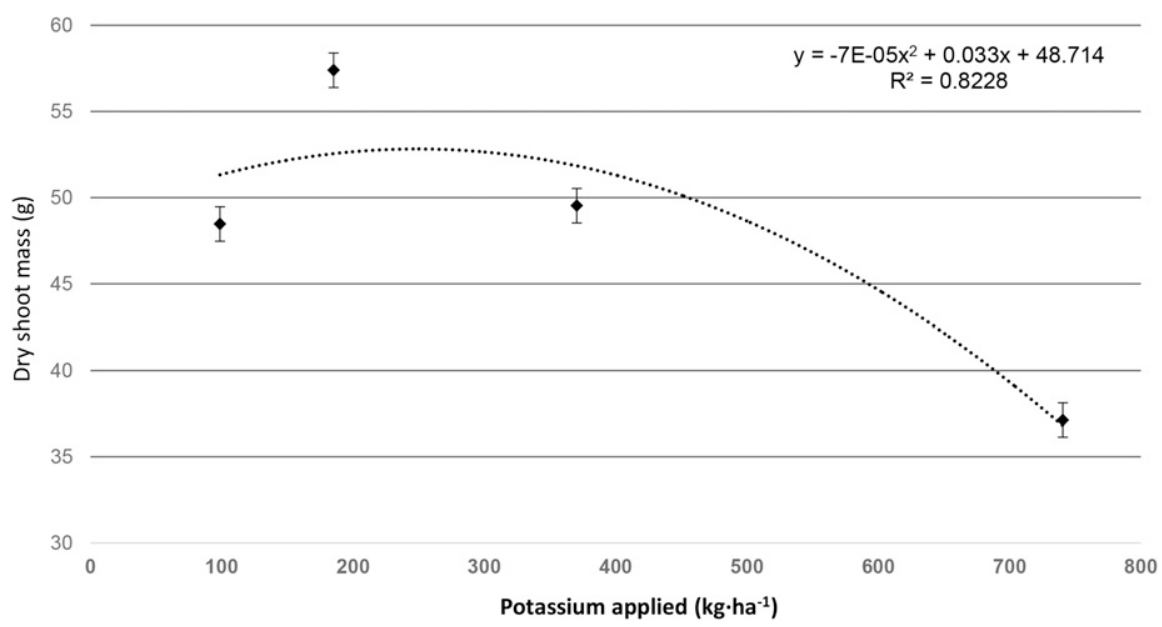

Fig. 2. The effect of adequate and elevated levels of potassium on dry weight of greenhouse-grown red romaine lettuce plants harvested $56 \mathrm{~d}$ after seeding.

$y=-2 E-05 x^{2}+0.0182 x+31.352$ $R^{2}=0.6907$

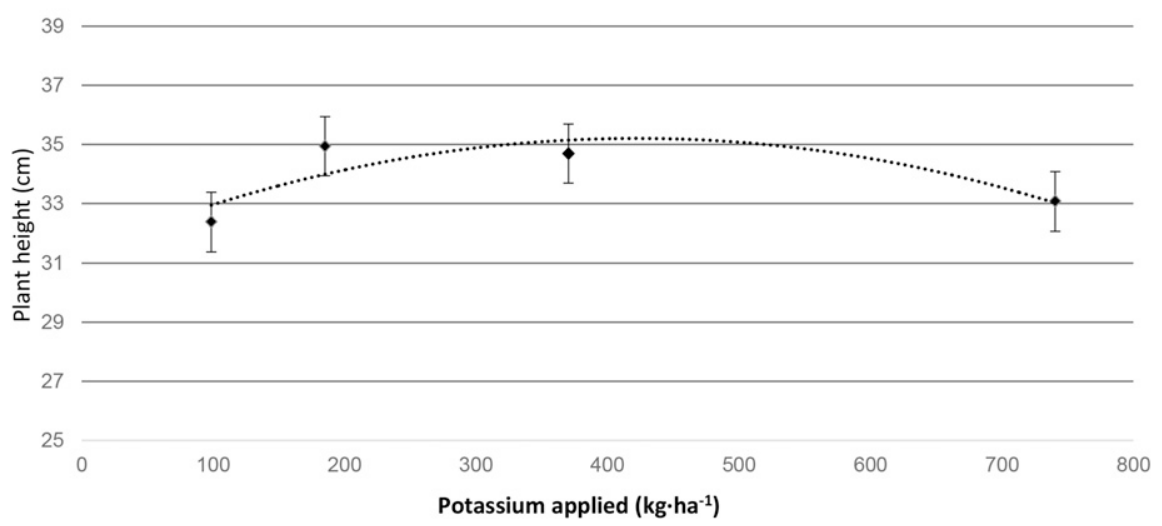

Fig. 3. The effect of adequate and elevated levels of potassium on plant height of greenhouse-grown red romaine lettuce plants harvested $56 \mathrm{~d}$ after seeding.

significant differences in levels of $\mathrm{P}$ and Mo in red romaine lettuce leaf tissue (Table 1).

Influence of increasing $K$ treatments on red romaine lettuce soluble sugars. The increasing levels of $\mathrm{K}$ significantly increased sucrose concentrations (Fig. 4). Sucrose concentrations increased $\approx 30 \%$, from $7.61 \mathrm{mg} \cdot \mathrm{g}^{-1}$
$110.72 \mathrm{mg} \cdot \mathrm{g}^{-1} \mathrm{DW}$ in $3 \times$ treatment, and then increasing to $115.52 \mathrm{mg} \cdot \mathrm{g}^{-1}$ in the $8 \times$ treatment. Increasing levels of $\mathrm{K}$ did not significantly influence glucose concentrations (Fig. 6). Total sugars had a negative quadratic response to increasing $\mathrm{K}$ treatments (Fig. 7). Total sugar concentrations were $151.20 \mathrm{mg} \cdot \mathrm{g}^{-1} \mathrm{DW}$ in the control treatment, decreasing to $140.75 \mathrm{mg} \cdot \mathrm{g}^{-1} \mathrm{DW}$ in $2 \times$ treatments and $140.47 \mathrm{mg} \cdot \mathrm{g}^{-1} \mathrm{DW}$ in $3 \times$ treatment, and then increasing to $151.20 \mathrm{mg} \cdot \mathrm{g}^{-1}$ DW in the $8 \times$ treatment.

\section{Discussion}

The current study examines how adequate and elevated levels of $\mathrm{K}$ fertilizer affect red romaine lettuce plant height, biomass, mineral nutrient uptake, and concentrations of soluble sugars. Although elevating levels of $\mathrm{K}$ fertilizer was beneficial for plant height and biomass of red romaine lettuce, a saturation point was reached and then there were negative effects at higher levels of $\mathrm{K}$ fertilizer applications. This was evident when applying $3 \times$ and $8 \times \mathrm{K}$ treatments. Field application of granular $\mathrm{K}$ fertilizers, such as potash, contain high levels of chloride especially at the $3 \times$ and $8 \times$ treatment levels. These high levels can create salt stress that can reduce growth and development, yields, and other metabolites, such as soluble sugars, in lettuce leaf tissues. For example, previous research on field grown lettuce, cabbage (Brassica oleracea), and celery (Apium graveolens) also indicated that oversupply of $\mathrm{K}$ depresses plant growth and yield (Inthichack et al., 2012). However, these findings are not consistent with other research on lettuce. For instance, Fallovo et al. (2009a, 2009b) demonstrated that changes in nutrient solution with $\mathrm{K}$ and other nutrients did not affect lettuce yield and quality. In addition, Soundy et al. (2001) found that elevating $\mathrm{K}$ in the nutrient solution for hydroponically grown lettuce did not affect growth rate or shoot and root biomass accumulation. The reason why results do not support previous research may be found in the medium the lettuce plants were grown. The current study treated lettuce plants with elevated levels of $\mathrm{K}$ in a soilless medium, while Fallovo et al. (2009a, 2009b) and Soundy et al. (2001) treated the hydroponic solution with different concentrations of $\mathrm{K}$. In a soilless medium, plants are able to take up nutrients as they become available from the soil solution, which depends on buffering capacity, $\mathrm{pH}$, and moisture. In contrast, purified water is normally used for hydroponic solutions and has minimal buffering capacity and constant water supply. This allows the plants to take up nutrients readily from the nutrient solution when the $\mathrm{pH}$ is maintained between 5.5 and 6.0.

Excess $\mathrm{K}$ supply has an impact on the uptake of other mineral nutrients such as $\mathrm{Ca}$ and $\mathrm{Mg}$. In these instances, the cytosol becomes less negative due to the influx of $\mathrm{K}$. This depolarization reduces the driving force for the uptake of other cationic species, which are otherwise taken up by facilitated 
Table 1. Elemental nutrient concentrations of greenhouse-grown 'Cimmaron' red romaine lettuce plants at adequate and elevated levels of potassium.

\begin{tabular}{|c|c|c|c|c|c|c|c|c|c|c|c|c|}
\hline \multirow[b]{2}{*}{ Potassium $\left(\mathrm{kg} \cdot \mathrm{ha}^{-1}\right)$} & \multicolumn{12}{|c|}{ Elemental nutrient concentrations $\left[\mathrm{mg} \cdot \mathrm{g}^{-1} \text { dry weight }(\mathrm{DW})\right]^{\mathrm{z}, \mathrm{y}}$} \\
\hline & $\mathrm{Na}$ & $\mathrm{Mg}$ & $\mathrm{P}$ & $\mathrm{S}$ & $\mathrm{K}$ & $\mathrm{Ca}$ & B & $\mathrm{Mn}$ & $\mathrm{Fe}$ & $\mathrm{Cu}$ & $\mathrm{Zn}$ & $\mathrm{Mo}^{\mathrm{x}}$ \\
\hline 185.17 & 1.19 & 6.51 & 5.40 & 2.53 & 48.80 & 10.65 & 0.03 & 0.30 & 0.55 & 0.05 & 0.09 & 0.04 \\
\hline \multicolumn{13}{|l|}{ Contrast } \\
\hline Linear & * & ** & NS & $* *$ & ** & ** & ** & NS & * & NS & NS & NS \\
\hline Quadratic & NS & NS & NS & NS & * & NS & * & * & NS & $*$ & $* * *$ & NS \\
\hline
\end{tabular}

${ }^{\mathrm{z}} \mathrm{Na}=$ sodium $; \mathrm{Mg}=$ magnesium; $\mathrm{P}=$ phosphorus; $\mathrm{S}=$ sulfur; $\mathrm{K}=$ potassium; $\mathrm{Ca}=$ calcium; $\mathrm{B}=$ boron; $\mathrm{Mn}=$ manganese $\mathrm{Fe}=$ iron; $\mathrm{Cu}=$ copper; $\mathrm{Zn}=$ zinc; Mo $=$ molybdenum

${ }^{\mathrm{y}} \mathrm{The}$ standard error of the mean was $\mathrm{Na} \pm 0.16 ; \mathrm{Mg} \pm 0.70 ; \mathrm{P} \pm 0.50 ; \mathrm{S} \pm 0.31 ; \mathrm{K} \pm 4.65 ; \mathrm{Ca} \pm 1.41 ; \mathrm{B} \pm 0.002 ; \mathrm{Mn} \pm 0.04 ; \mathrm{Fe} \pm 0.08 ; \mathrm{Cu} \pm 0.007 ; \mathrm{Zn} \pm 0.005$; Mo \pm 0.01 .

${ }^{\mathrm{x}}$ Mo given as $\mu \mathrm{g} \cdot \mathrm{g}^{-1} \mathrm{DW}$.

Ns, * **, ***Nonsignificant or significant at $P \leq 0.05,0.01,0.001$, respectively.

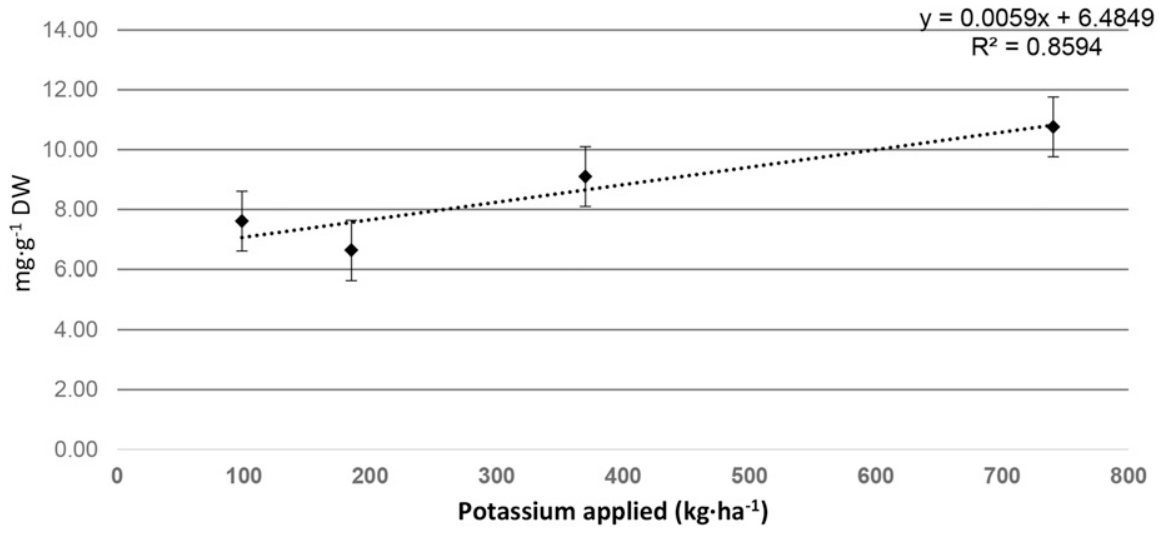

Fig. 4. Sucrose concentrations of greenhouse-grown red romaine lettuce plants treated with adequate and elevated potassium levels and harvested $56 \mathrm{~d}$ after seeding.

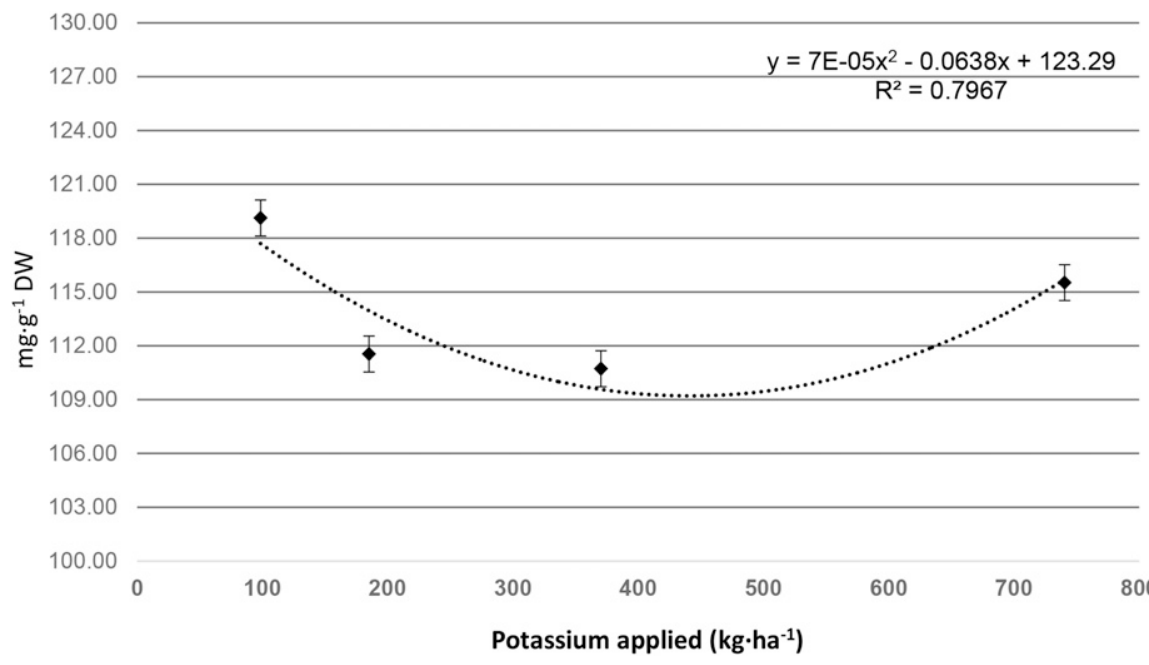

Fig. 5. Fructose concentrations of greenhouse-grown red romaine lettuce plants treated with adequate and elevated potassium levels and harvested $56 \mathrm{~d}$ after seeding.

diffusion (Marschner, 2012). The current study corresponded to this decree by decreasing $\mathrm{Ca}$ and $\mathrm{Mg}$ in lettuce leaf tissue with increasing $\mathrm{K}$ application rate. Previous research has also demonstrated that growing season and nutrient solution composition affect N, K, and Mg uptake by plants. However, $\mathrm{Ca}$ concentrations did not differ with nutrient solution concentrations (Fallovo et al., 2009a, 2009b). These trends were evident in the current experiment with red romaine lettuce when plants were treated with elevated levels of $\mathrm{K}$, the uptake of $\mathrm{B}, \mathrm{Mg}, \mathrm{S}, \mathrm{Ca}$, and $\mathrm{Fe}$ in leaf tissue significantly decreased. Previous research has indicated that $\mathrm{K}$ concentrations can range from $\approx 25$ to $54 \mathrm{mg} \cdot \mathrm{g}^{-1}$ DW in the youngest fully developed leaves of lettuce (Bergmann, 1993). This research supports the results of the current study in which $\mathrm{K}$ concentration in the youngest fully developed leaves ranged from $\approx 31$ to $55 \mathrm{mg} \cdot \mathrm{g}^{-1} \mathrm{DW}$.

It is well established that $\mathrm{K}$ increases quality of fruits and vegetables by improving yields, color, firmness, and soluble sugars (Lester et al., 2010). Specifically, Li et al. (2008) found that foliar spray treatments improved tomato plant growth and vitamin $\mathrm{C}$, soluble sugars, and organic acids in the fruit. Research also indicated that application of potassium sulfate to the soil improved apple fruit quality, such as color, firmness, and soluble sugars (Attala, 1998; El-Gazzar, 2000). However, expansive research on yield and quality of leafy green vegetables in response to adequate and elevated levels of $\mathrm{K}$ fertilizer treatments is needed. Previous research on application of elevated $\mathrm{K}$ levels on leafy greens yielded inconclusive results. One study indicated that elevating $\mathrm{K}$ increased yield and decreased $\mathrm{Mg}$ and $\mathrm{Ca}$ in the leaf tissue of lettuce and other vegetables (Inthichack et al., 2012). Additional research has demonstrated that differing levels of $\mathrm{K}$ in the nutrient solution of hydroponically grown lettuce did not affect yield, biomass, and quality such as soluble sugars (Fallovo et al., 2009a, 2009b; Soundy et al., 2001). In the current study, even though levels of total sugar in the leaf tissue decreased with increasing levels of $\mathrm{K}$ application, there were increases in $\mathrm{FW}, \mathrm{DW}$, and plant height at the $2 \times$ and $3 \times \mathrm{K}$ applications. Monosaccharides, such as fructose and glucose, in red romaine lettuce leaf tissue decreased in concentration when levels of $\mathrm{K}$ fertilizer treatments increased. These results indicate that lettuce plants treated with elevated levels of $\mathrm{K}$ use the monosaccharides to build structural carbohydrates to add more biomass to the plant. Research has demonstrated inverse relationships between tissue concentrations of $\mathrm{K}$ and sugars, reducing sugars in particular, and can be observed during the growth of storage tissue. In carrot (Daucus carota), results indicated that an increase in the concentration of reducing sugars is compensated for by a corresponding decrease in the concentration of $\mathrm{K}$ and organic acid anions (Steingrover, 1983). These results correspond with the current study in that increasing the $\mathrm{K}$ concentrations in red romaine lettuce leaf tissue decreased the concentration of fructose and glucose. Thus, an inverse relationship of the concentrations 


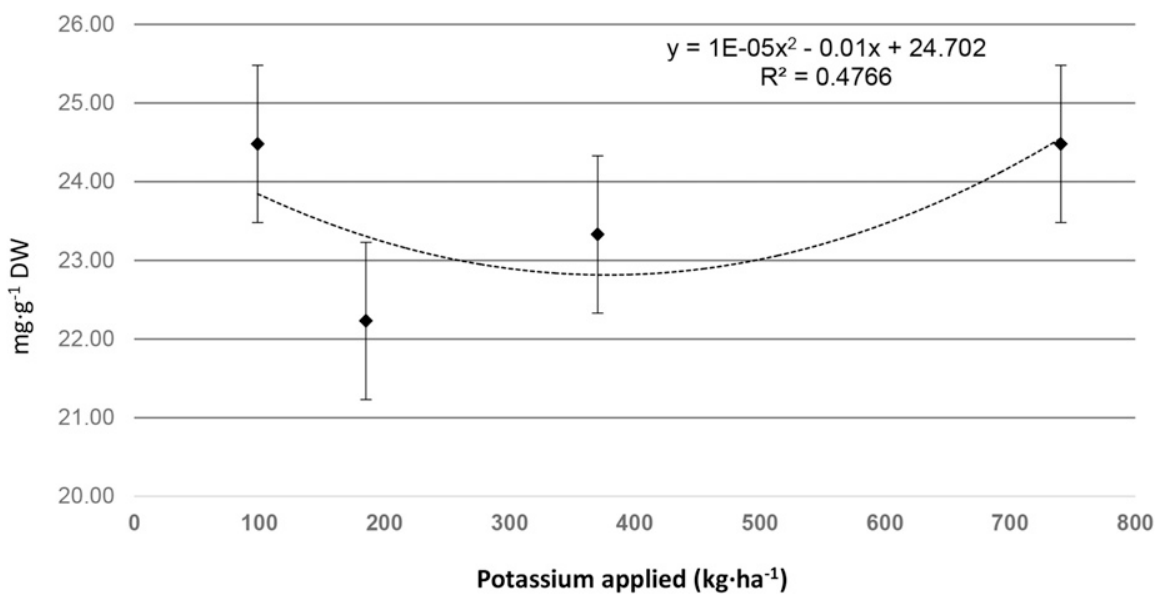

Fig. 6. Glucose concentrations of greenhouse-grown red romaine lettuce plants treated with adequate and elevated potassium levels and harvested $56 \mathrm{~d}$ after seeding.

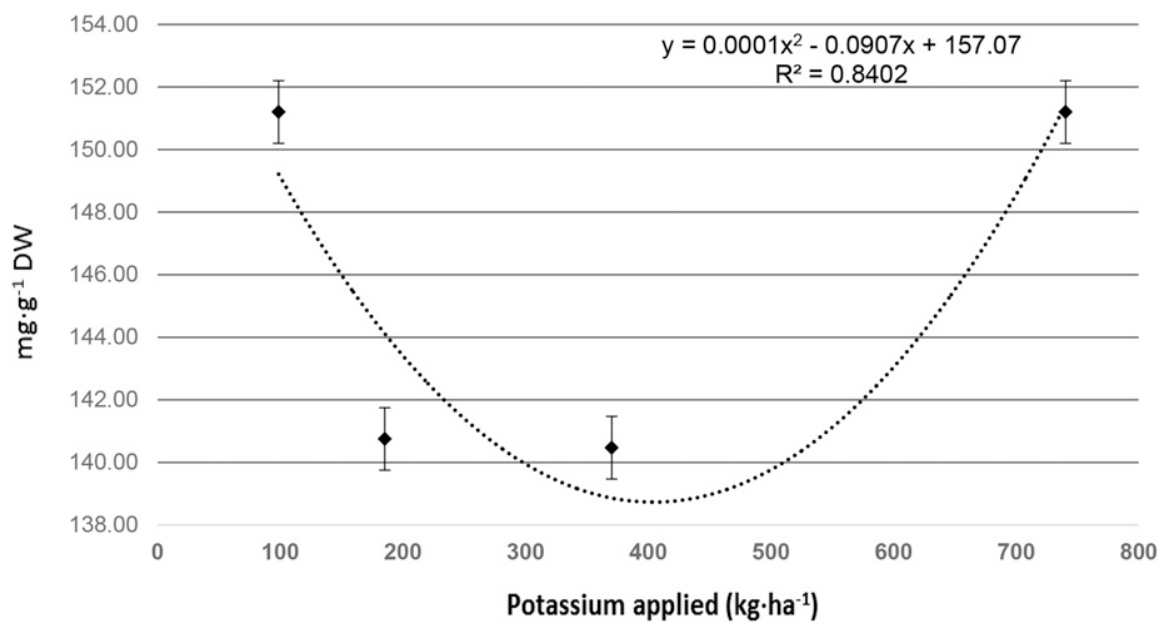

Fig. 7. Total soluble sugar concentrations of greenhouse-grown red romaine lettuce plants treated with adequate and elevated potassium levels and harvested $56 \mathrm{~d}$ after seeding.

between $\mathrm{K}$ and fructose and glucose was present. However, there was a point where adding $\mathrm{K}$ to lettuce plants increased the sugars. At the $8 \times \mathrm{K}$ fertilizer treatment, sugars again increased in lettuce leaf tissue. These results indicate that instead of adding more biomass there was an accumulation of soluble sugars in the leaf tissue, suggesting that there was a stronger source to sink relationship in the lettuce plant tissue.

The translocation of phloem-mobile nutrients, such as K, from shoots to roots together with photosynthetic carbon is a normal feature during ontogenesis (Jeschke and Pate, 1991). Although this translocation may serve specific regulatory functions for any particular mineral nutrient, it might also be the consequence of the mechanism of phloem loading photoassimilates, particularly sucrose, in the source leaves (Komor, 1994). Therefore, increasing the levels of $\mathrm{K}$ fertilizer treatments may also increase the levels of sucrose in the leaf tissue. In a previous study, Beringer et al. (2006) demonstrated that elevating $\mathrm{K}$ fertilizer concentrations increased sugar beet (Beta vulgaris) root DW from 269 to $310 \mathrm{~g}$ per plant. Furthermore, the authors were able to increase indicated from this study, $\mathrm{K}$ fertilizer treatments should range between 180 and $370 \mathrm{~kg} \cdot \mathrm{ha}^{-1}$ for soilless greenhouse and field production.

\section{Literature Cited}

Anathi, S., D. Veeraragavathatham, and K. Srinivasan. 2004. Influence of sources and levels of potassium on quality attributes of chili (Capsicum annuиm L.). South Indian Hort. 52:152-157.

Attala, E.S. 1998. Effect of potassium fertilization on Anna apple trees grown in sandy soils of Egypt. Egyptian J. Agr. Res. 76:709-719.

Barickman, T.C., D.A. Kopsell, and C.E. Sams. 2013. Selenium influences glucosinolate and isothiocyanates and increases sulfur uptake in Arabidopsis thaliana and rapid-cycling Brassica oleracea. J. Agr. Food Chem. 61:202-209.

Barickman, T.C., D.A. Kopsell, and C.E. Sams. Abscisic acid impacts tomato fruit quality by increasing carotenoids and soluble sugars and decreasing organic acids. HortScience. (In press).

Bergmann, W. 1993. Ernahrungsstorungen bei Kulturpflanzen-Entstehung und Diagnose, p. 384-394. 3rd ed. VEB Gustav Fischer Verlag, Jena, Germany.

Beringer, H., K. Koch, and M. Lindhauer. 2006 Sucrose accumulation and osmotic potential in sugar beet at increasing levels of potassium nutrition. J. Sci. Food Agr. 37:211-218.

Bres, W. and L.A. Weston. 1992. Nutrient accumulation and tipburn in NFT-grown lettuce at several potassium and $\mathrm{pH}$ levels. HortScience 27:790-792.

Dutta, P., A.K. Chakroborty, and P.K. Chakroborty. 2003. Effect of different levels of potassium on fruit quality and yield of sweet orange. Ann. Agr. Res. 24:786-788.

El-Gazzar, A.A.M. 2000. Effect of fertilization with nitrogen, potassium and magnesium on Anna apples: 2-Effect of potassium fertilization. Ann. Agr. Sci. Cairo. 3:1153-1160.

Eskins, K., K. Warner, and F.C. Felker. 1995. Light quality during early seedling development influences the morphology and bitter taste intensity of mature lettuce (Lactuca sativa) leaves J. Plant Physiol. 147:709-713.

Fallovo, C., Y. Rouphael, M. Cardarelli, E. Rea, A. Battistelli, and G. Colla. 2009a. Yield and quality of leafy lettuce in response to nutrient solution composition and growing season. J. Food Agr. Environ. 2:456-462.

Fallovo, C., Y. Rouphael, E. Rea, A. Battistelli, and G. Colla. 2009b. Nutrient solution concentration and growing season affect yield and quality of Lactuca sativa L. var. acephala in floating raft culture. J. Sci. Food Agr. 89:1682-1689.

Fanasca, S., G. Colla, Y. Rouphael, F. Saccardo, G. Maiani, E. Venneria, and E. Azzini. 2006. Evolution of nutritional value of two tomato genotypes grown in soilless culture as affected by macrocation proportions. HortScience 41: $1584-1588$

Hoque, M.M., H. Ajwa, M. Othman, R. Smith, and M. Cahn. 2010. Yield and postharvest quality of lettuce in response to nitrogen, phosphorus, and potassium fertilizers. HortScience 45:1539-1544.

Inthichack, P., Y. Nishimura, and Y. Fukumoto. 2012. Effects of potassium source and rates on plant growth, mineral absorption, and the incidence of tip burn in cabbage, celery, and lettuce. Hort. Environ. Biotechnol. 53:135-142.

Jeschke, W.D. and J.S. Pate. 1991. Modelling of the partitioning assimilation and storage of nitrate within root and shoot organs of castor bean (Ricinus communis L.). J. Expt. Bot. 42:1091-1103. 
Jifon, J.L. and G.E. Lester. 2009. Foliar potassium fertilization improves fruit quality of fieldgrown muskmelon on calcareous soils in south Texas. J. Sci. Food Agr. 89:2452-2460.

Kleinhenz, M.D., D.G. French, A. Gazula, and J.C. Scheerens. 2003. Variety, shading, and growth stage effects on pigment concentrations in lettuce grown under contrasting temperature regimens. HortTechnology 4:677-683.

Komor, E. 1994. Regulation of futile cycles: The transporter of carbon and nitrogen in plants, p. 153-210. In: E.D. Schulze (ed.). Flux control in biological systems, from enzymes to populations and ecosystems. Academic Press, London, UK.

Lester, G.E., J.L. Jifon, and G. Rogers. 2005. Supplemental foliar potassium applications during muskmelon (Cucumis melo L.) fruit development can improve fruit quality, ascorbic acid and beta-carotene contents. J. Amer. Soc. Hort. Sci. 130:649-653.

Lester, G.E., J.L. Jifon, and D.J. Makus. 2006. Supplemental foliar potassium applications with and without surfactant can enhance netted muskmelon quality. HortScience 41: 741-744.
Lester, G.E., J.L. Jifon, and D.J. Makus. 2010. Impact of potassium nutrition on postharvest fruit quality: Melon (Cucumis melo L.) case study. Plant Soil 335:117-131.

Li, R.H., D.B. Xu, and Q.W. Huang. 2008. Effect of foliar fertilizer on the growth of tomato plant. China Veg. 6:17-20.

Luo, H.Y., J. He, and S.K. Lee. 2012. Interaction between potassium concentration and root-zone temperature on growth and photosynthesis of temperate lettuce grown in the tropics. J. Plant Nutr. 35:1004-1021.

Marschner, H. 2012. Functions of mineral nutrients: Macronutrients, p. 299-312. In: H. Marschner (ed.). Mineral Nutrition of Higher Plants. Academic Press, New York, NY.

Mossler, M.A. and E. Dunn. 2005. Florida crop/ pest management profile: Lettuce. Pesticide Information Office, Agronomy Department, UF/IFAS Extension. CIR1460.

Nava, G., A. Roque-Dechen, and G. Ribeiro-Nachtiga. 2008. Nitrogen and potassium fertilization affect apple fruit quality in southern Brazil. Commun. Soil Sci. Plant Anal. 39:96-107.

Petrazzini, L.L., G.A. Souza, C.L. Rodas, E.B. Emrich, J.G. Carvalho, and R.J. Souza. 2014
Nutritional deficiencies in crisphead lettuce grown in hydroponics. Hort. Bras. 32:310-313. Soundy, P., D.J. Cantliffe, G.J. Hochmuth, and P.J. Stoffella. 2001. Nutrient requirements for lettuce transplants using a floatation irrigation system II. Potassium. HortScience 36: 1071-1074.

Srivastava, A.K., A.D. Huchche, R. Lallan, and S. Shyam. 2001. Pre- and post-havest response of Nagpur mandarin (Citrus reticulate Blanco) to $\mathrm{K}$ fertilization in Typic Haplustert. J. Potassium Res. 17:93-97.

Steingrover, E. 1983. Storage of osmotically active compounds in the taproot of Daucus carota L. J. Expt. Bot. 34:425-433.

Taber, H., P. Perkins-Veazie, S.S. Li, W. White, S. Rodermel, and Y. Xu. 2008. Enhancement of tomato fruit lycopene by potassium is cultivar dependent. HortScience 43:159-165.

Wojcik, P. 2005. Effect of foliar potassium spray on apple tree yielding, and fruit quality under conditions of low soil potassium availability. Proceedings International Scientific Conference: Environmentally friendly fruit growing, Polli, Estonia, 7-9 Sept. 2005, p. $44-50$. 